J. Perinat. Med.

11 (1983) 103

\section{Investigations on neonatal cardiopulmonary reanimation using an animal model}

\author{
E. Traub, W. Dick, P. Lotz, K.-H. Lindner, K. Engels
}

Center for Anaesthesiology, Ulm University

(Heads: Prof.Dr.F.W. Ahnefeld, Prof.Dr.W.Dick, Prof.Dr.Dr. A.Grünert)

\section{Introduction}

Failure of cardio-respiratory function is the cause of approximately $74 \%$ of all neonatal deaths [3]. Regardless of whether the cause of this failure is maternal, placental or fetal, cardiopulmonary reanimation must be started as soon as possible in all cases of cardio-circulatory stillstand when this occurs immediately pre- or postpartum. On the other hand, neonatal bradycardias very rarely need to be treated with cardiac massage, because adequate ventilation alone usually results in the heart rate becoming normal.

The technique of cardiopulmonary resuscitation as used for adults has been widely recommended for the primary resuscitation of neonates $[2,3,4,5,6$, $7,10,12,13,14,15]$.

A search of the literature failed to reveal either experimental or clinical studies on which to base the technique to be used for neonates. It seems reasonable to assume however, that optimal ventilation and cardiac compression rates, and the relation one to another should lie within normal physiological limits.

This study was carried out using standardized conditions and an animal model in order to determine whether the recommended ratio of ventilation to cardiac massage of $1: 5$ [1] results in respiratory and hemodynamic function which is comparable, or better than, rates which are based on the physiological norms (ventilation rate of approximately $40 / \mathrm{min}$, heart rate of

\section{Curriculum vitae}

Preclinical and clinical medical study at Heidelberg University between 1956 and 1962. Finals completed in 1962. On completion of internship, further clinical work in the Medical Department of Ulm General Hospital. Between 1967 and 1970 specialisation in anaesthesiology in the Anaesthetics Department of Ulm University. Since 1971 registar at the Anaesthesiology

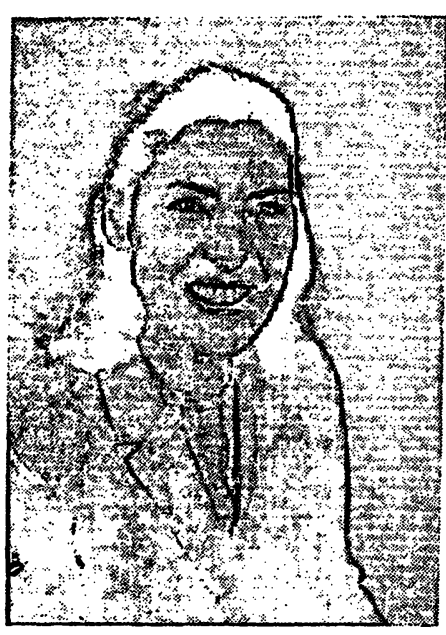
Department of Ulm University. Main interests: Gynaecological and obstetric anaesthetics and intensive care. Neonatal reanimation.

approximately $120 / \mathrm{min}$, ventilation: compression ratio of $1: 3$ or a multiple thereof).

The effect of using positive end-exspiratory pressure ventilation from the beginning of reanimation was also investigated in this study.

\section{Methods}

24 piglets of body weight between 4 and $5 \mathrm{~kg}$ and age between 2 and 3 weeks were used for the study.

The animals were randomized into four different groups: 
1. Respiratory rate 30 , zero end-exspiratory pressure (ZEEP) 6 animals.

2. Respiratory rate 40, ZEEP 6 animals

3. Respiratory rate 30 , positive end-exspiratory pressure (PEEP) 6 animals

4. Respiratory rate 40, PEEP 6 animals.

Reanimation with three various ventilation: compression ratios $-1: 2,1: 3$ and $1: 4$ each carried out for 10 minutes, was carried out on each of the animals. In order to exclude progressive changes occurring during the course of reanimation from confusing the results, the sequence in which the three various ratios were applied was also randomized.

The animals were first anaesthetized with an intraperitoneal injection of Nembutal, and were then given a muscle relaxant and intubated. After a steady state had been achieved under mechanical ventilation (Servo-Ventilator) and $100 \%$ oxygen, and after the internal jugular vein, common carotid artery and femoral artery had been cannulated, cardiac arrest was induced with an intravenous injection of $10 \mathrm{ml}$ of potassium chloride solution $(1 \mathrm{mmol} / \mathrm{ml})$. In the subsequent reanimation phase the animals were ventilated at a rate of either 30 or $40 / \mathrm{min}$ using a baby AMBU-Bag. In two of the groups a positive end-exspiratory pressure of $5 \mathrm{~cm} \mathrm{H}_{2} \mathrm{O}$ was applied, using an AMBU-PEEP-valve.

Cardiac massage was carried out by manual external compression of the thorax with the animals in the supine position, at a frequency of between 60 and $160 / \mathrm{min}$.

Arterial blood-gas and acid-base analyses were carried out at $5 \mathrm{~min}$. intervals, so that for each ratio used two separate measurements were made. The systolic arterial pressure was monitored during the whole period of reanimation using a continuous tracing, and mean arterial pressure was recorded from the monitor used, every thirty seconds. In the following, these parameters are represented by the value at the midpoint of each 5 min. interval.

Serum lactate concentration was measured at the end of each of the three phases of reanimation. Exspiratory volume and $\mathrm{CO}_{2}$-concentrations was measured by collecting the exspiratory gases in two parallel DoUGLAS bags over 5 min. intervals.
Calculation of the respiratory minute volume, tidal volume, dead space volume and alveolararterial difference in partial pressure of oxygen was based on the blood gas and above mentioned measurements of respiratory function. $\mathrm{CO}_{2}$-production was used as a parameter for the degree of aerobic metabolism occurring.

\subsection{Statistical methods}

The mean and standard deviation of all the 5 and 10 minute values were calculated. The various ventilation: cardiac compression ratios were compared using the mean values of all the animals at the same points in time, using Student's paired t-test.

Comparisons between the ZEEP- and PEEP-groups and between the respiratory rates of 30 and 40 were carried out by comparing identical points in time using WiLCOXON's U-test for the comparison of two independent samples.

\section{Results}

\subsection{Comparison of ventilation:} compression ratios of $1: 2,1: 3$, and $1: 4$

\subsubsection{Cardio-circulatory parameters}

A slight fall in mean systolic pressure (Fig. 1) was found to be associated with the higher cardiac compression rates. The values at 10 minutes were lower than those at 5 in all groups. During the intervals between thoraxic compression a diastolic pressure of approximately $5 \mathrm{~mm} \mathrm{Hg}$ was recorded. The mean arterial pressure of all groups was approximately $25 \mathrm{~mm} \mathrm{Hg}$, here again the pressures recorded at 10 minutes were not as high as those at 5 minutes.

\subsubsection{Respiratory function}

The arterial partial pressure of oxygen (Fig. 2) showed no differences during the various ventilation: compression ratios. At the end of the first phase of reanimation the $\mathrm{Po}_{2}$-values of the three groups were all approximately $150 \mathrm{~mm} \mathrm{Hg}$, and $10 \mathrm{~min}$. later all had decreased by about 15-20 mm Hg. The $\mathrm{P}_{\mathrm{CO}_{2}}$-values lay between 29 

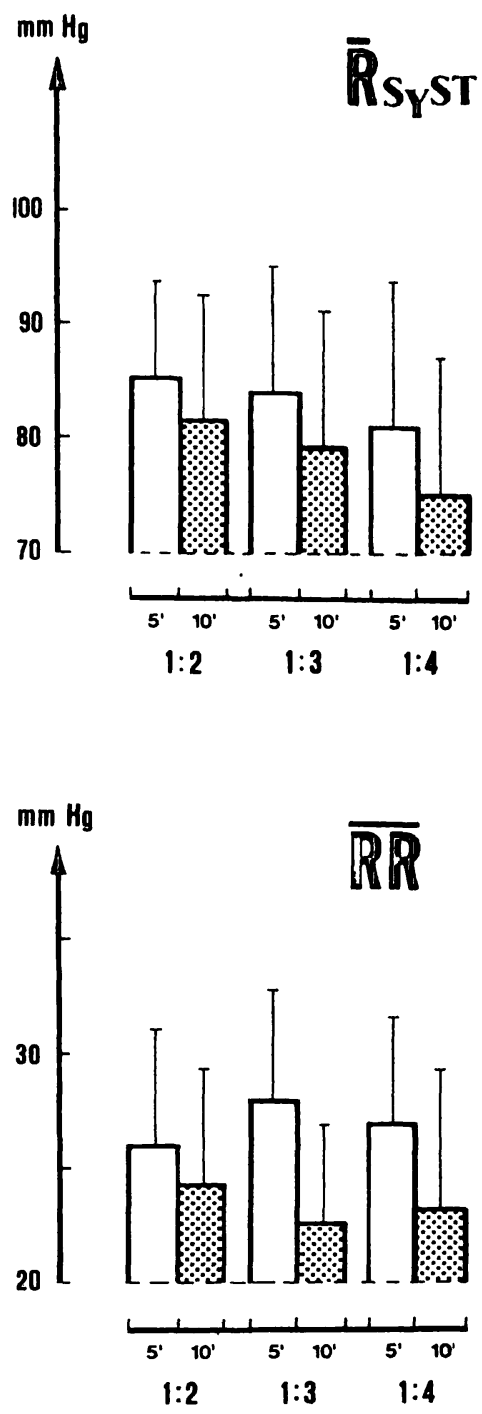

Fig. 1. Mean and systolic arterial pressure during cardiopulmonary reanimation under the influence of varying ventilation compression ratios after intervals of 5 and $10 \mathrm{~min}$. Mean values and standard deviation.

and $37 \mathrm{~mm} \mathrm{Hg}$. A slight increase was observed during the course of reanimation. Only slight changes were found in the respiratory minute volume and tidal volume during application of the three various ratios.

The very high values of the ratio between dead space and tidal volume of between 0.8 and 0.9 (Fig. 3) are the results of the very low, effective pulmonary perfusion. Similarly, the alveoloarterial difference in partial pressure of oxygen which can be regarded as a parameter of the intrapulmonary right to left shunt, indicated a marked increase in shunt.
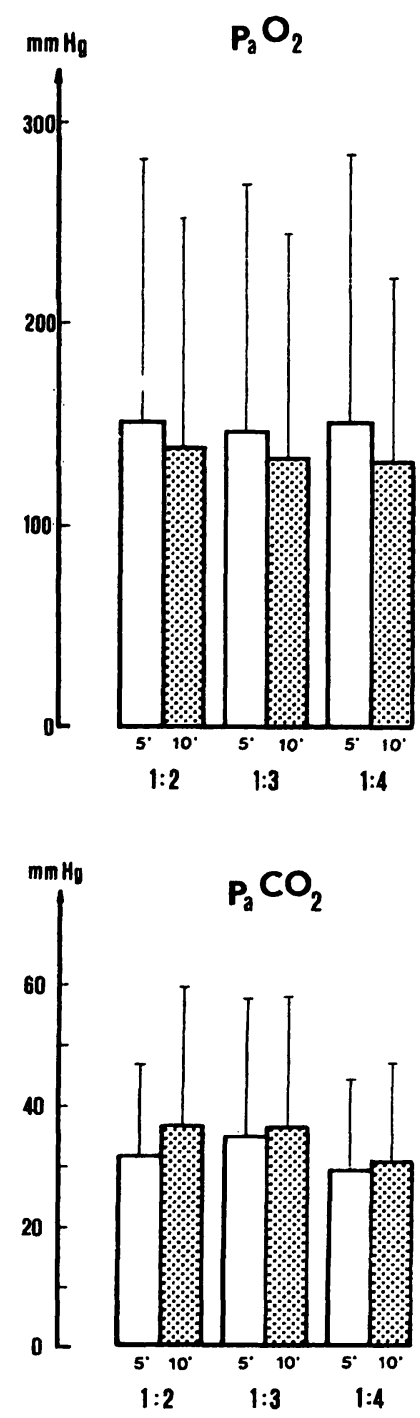

Fig. 2. Mean values of $\mathrm{PaO}_{2}$ and $\mathrm{PaCO}_{2}$ during cardiopulmonary reanimation under the influence of varying ventilation compression ratios after intervals of 5 and $10 \mathrm{~min}$. Mean values and standard deviation.

\subsubsection{Metabolic parameters}

No significant differences in the arterial $\mathrm{pH}$-values (Fig. 4) could be found between the three groups. The serum lactate levels at ten min. were in all groups approximately $12 \mathrm{mmol} / 1$, an indication of the very marked metabolic acidosis present.

The highest $\mathrm{CO}_{2}$-production (Fig. 5), which under these standardized conditions can be regarded as a parameter of aerobic-metabolism, were found when a ventilation: compression ratio of $1: 3$ was used. This difference was not statisticly significant however. 


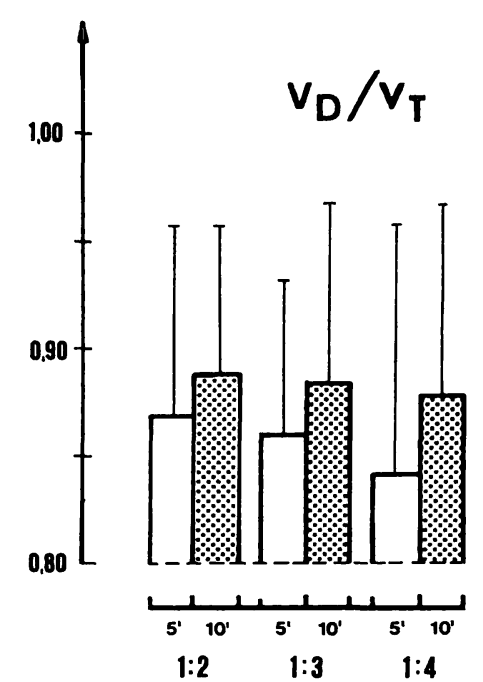

$\mathrm{AaDO}_{2}$

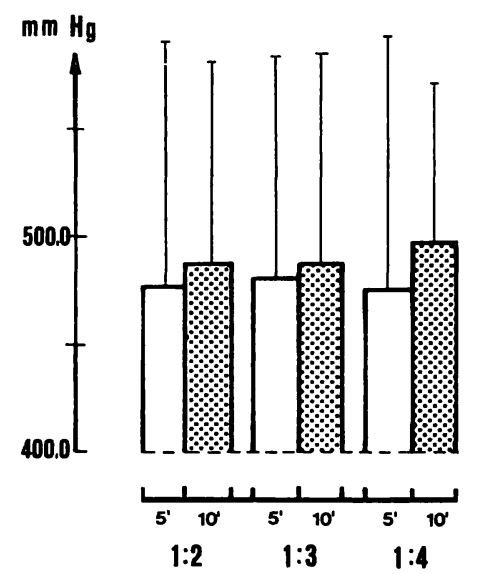

Fig. 3. The influence of varying ventilation compression ratios on the dead space/tidal volume ratio and the alveolo-arterial difference in oxygen partial pressure during cardiopulmonary reanimation. Mean values and standard deviation.

\subsection{Respiratory rate of 30 or $40 / \mathrm{min}$., ZEEP and PEEP}

\subsubsection{Cardio-circulatory parameters}

The pre-arrest mean arterial pressures lay between 60 and $70 \mathrm{~mm} \mathrm{Hg}$. During cardiopulmonary reanimation this value fell in all the groups to approximately $20-30 \mathrm{~mm} \mathrm{Hg}$ and remained at this level during whole course of the investigation.

Significant differences between the groups could not be found.
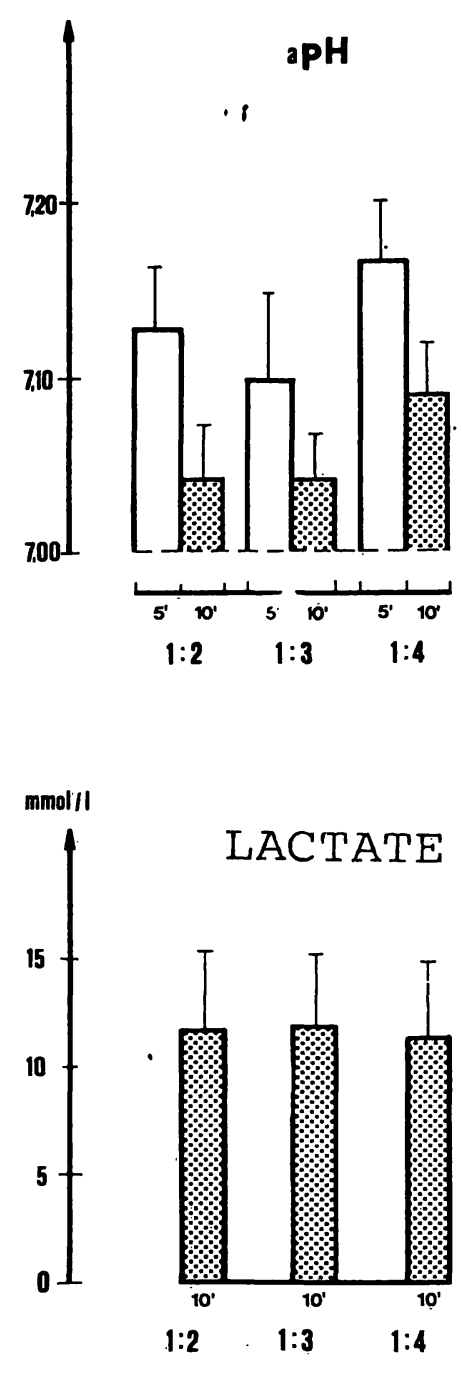

Fig. 4. Levels of pH- and serum lactate during cardiopulmonary reanimation under the use of varying ventilation compression ratios. Mean values and standard deviation.

\subsubsection{Respiratory parameters}

Prior to cardiac arrest, arterial $\mathrm{Po}_{2}$-values lay between 300 and $400 \mathrm{~mm} \mathrm{Hg}$ (Fig. 6). During reanimation an average value of $70 \mathrm{~mm} \mathrm{Hg}$ was found in both ZEEP- and PEEP-groups which were ventilated at a rate of $40 / \mathrm{min}$. Increasing respiratory rate and using zero end-exspiratory pressure resulted in an almost constant value of $100 \mathrm{~mm} \mathrm{Hg}$. The combined use of the higher respiratory rate and a PEEP of $5 \mathrm{~cm} \mathrm{H}_{2} \mathrm{O}$ resulted in a highly significant increase of $\mathrm{PaO}_{2}$ to average 


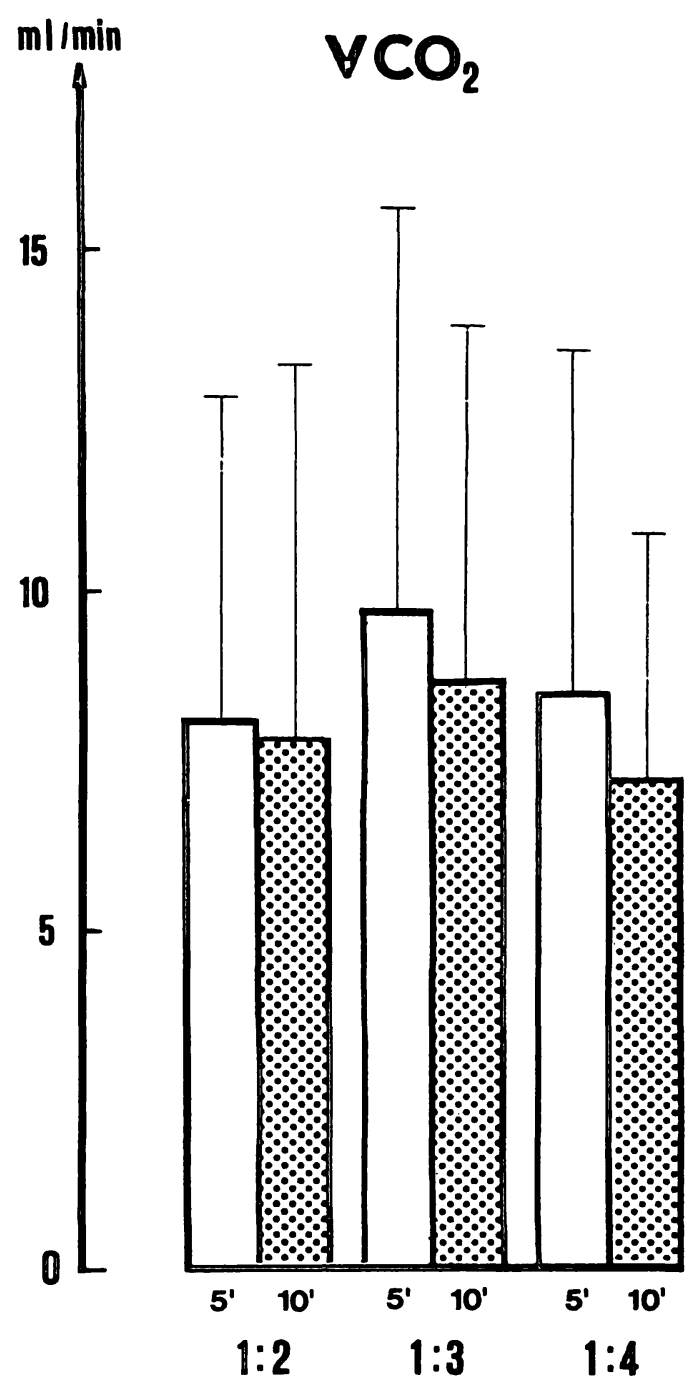

Fig. 5. $\mathrm{CO}_{2}$-production during cardiopulmonary reanimation under the influence of varying ventilation compression ratios. Mean values and standard deviations.

values of $158-227 \mathrm{~mm} \mathrm{Hg}$ (Tab. I). It must be said however, that the animals of this group had, on average, markedly higher $\mathrm{PaO}_{2}$-values prior to beginning reanimation, namely $405 \mathrm{~mm} \mathrm{Hg}$, as compared to $315 \mathrm{~mm} \mathrm{Hg}$ in the group ventilated with a respiratory rate of 40 and ZEEP.

The median $\mathrm{PaCO}_{2}$-values varied between 30 and $47 \mathrm{~mm} \mathrm{Hg}$ during use of a respiratory rate of $30 / \mathrm{min}$. On increasing the respiratory rate these values fell to between 20 and $30 \mathrm{~mm} \mathrm{Hg}$. Tidal volume was found to be lower at the higher respiratory rate, and slightly less during the use of PEEP as compared to ZEEP.

The first $5 \mathrm{~min}$. ratio of dead space to tidal volume was very high (between 0.8 and 0.9 ) an indication to the low effective pulmonary perfusion after this short space of time already. During the further course of reanimation this value approached 1.0 (Fig. 7). The group ventilated with a respiratory rate of 40 and PEEP had, also with respect to this parameter, more physiological values. The alveolararterial difference in partial pressure of oxygen showed similar changes.

\subsubsection{Metabolic parameters}

$\mathrm{CO}_{2}$-production was higher in the groups ventilated at $40 / \mathrm{min}$ and was lower in the PEEP than in the ZEEP ventilated groups. No significant differences could be calculated however (Fig. 8).

\section{Discussion}

The general principles of cardiopulmonary reanimation following neonatal cardiac arrest are no different to those applied to adults, the wholly different physiological parameters of respiratory and cardiovascular function must be born in mind however. For the first part of our investigation we therefore chose to evaluate the effects of respiratory frequency and cardiac compression rates and the ratio of these two one to another.

With respect to size, weight and thoraxic cage anatomy the piglets of three - four $\mathrm{kg}$ body weight used can be accepted as a reasonable animal model. The marked and rapid circulatory and respiratory readjustments present at birth are of cause no longer present in these animals, hence results defined by animal experiments such as these cannot be regarded as wholly representative of the human situation.

As previous experiments conducted on pigs of approximately $25 \mathrm{~kg}$ body weight have shown, cardiac minute volume falls to about a third of the initial value during cardiopulmonary reanimation. The technique and equipment for the measurement of cardiac minute volume cannot be used on small animals, so that we had to leave out measurement of the cardiac minute volume and arterial flow.

Independent of the ventilation and compression rates used and of their one to another, all parameters measured showed a change from normal 

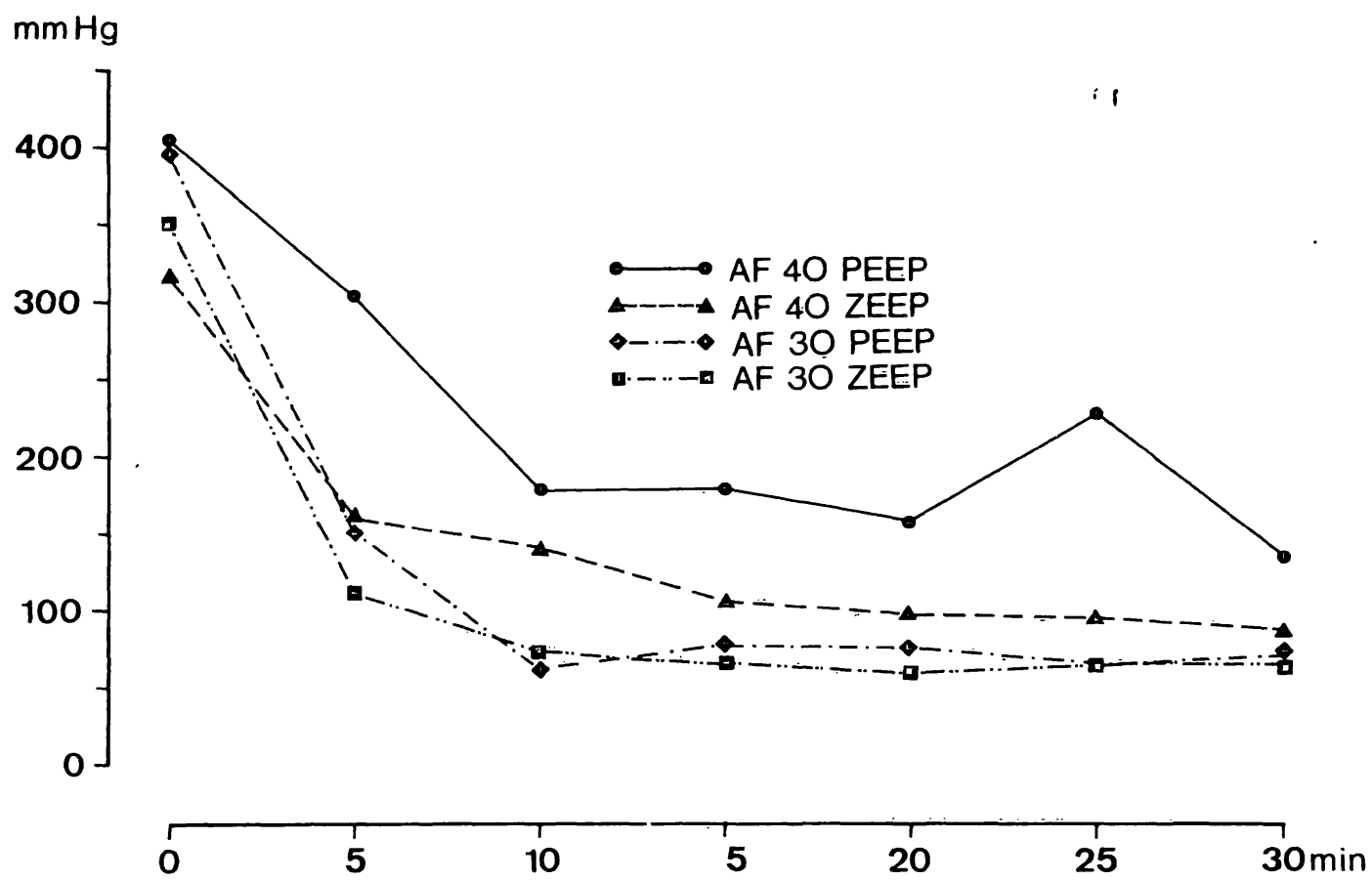

Fig. 6. Median $\mathrm{PaO}_{2}$-values during the course of cardiopulmonary reanimation using a respiratory rate of 30 or $40 / \mathrm{min}$ and either ZEEP or PEEP.

Tab. I. Median values of the measured and calculated parameters obtained during cardiopulmonary reanimation using respiratory rate of either 30 or $40 / \mathrm{min}$ and either ZEEP or PEEP of $5 \mathrm{~cm} \mathrm{H}_{2} \mathrm{O}$ at 5 and $10 \mathrm{~min}$. after commencing the phase of reanimation.

\begin{tabular}{|c|c|c|c|c|c|c|c|c|}
\hline & \multicolumn{4}{|l|}{ AF 30} & \multicolumn{4}{|l|}{$\mathrm{AF} 40$} \\
\hline & $\begin{array}{l}\text { ZEEP } \\
\mathrm{n}=6 \\
5^{\prime}\end{array}$ & $10^{\prime}$ & $\begin{array}{l}\text { PEEP } \\
n=6 \\
5^{\prime}\end{array}$ & $10^{\prime}$ & $\begin{array}{l}\text { ZEEP } \\
\mathrm{n}=6 \\
5^{\prime}\end{array}$ & $10^{\prime}$ & $\begin{array}{l}\text { PEEP } \\
\mathrm{n}=6 \\
5^{\prime}\end{array}$ & $10^{\prime}$ \\
\hline $\begin{array}{l}\mathrm{RR} \\
(\mathrm{mm} \mathrm{Hg})\end{array}$ & $\begin{array}{l}32 \\
(0.6-39)\end{array}$ & $\begin{array}{l}30 \\
(0.7-56)\end{array}$ & $\begin{array}{l}30 \\
(4-47)\end{array}$ & $\begin{array}{l}23 \\
(1-47)\end{array}$ & $\begin{array}{l}27 \\
(6-38)\end{array}$ & $\begin{array}{l}23 \\
2(39)\end{array}$ & $\begin{array}{l}30 \\
(9-40)\end{array}$ & $\begin{array}{l}23 \\
(11-43)\end{array}$ \\
\hline $\begin{array}{l}\mathrm{PaO}_{2} \\
(\mathrm{~mm} \mathrm{Hg})\end{array}$ & $\begin{array}{l}69 \\
(41-348)\end{array}$ & $\begin{array}{l}69 \\
(33-349)\end{array}$ & $\begin{array}{l}79 \\
(31-413)\end{array}$ & $\begin{array}{l}65 \\
(25-323)\end{array}$ & $\begin{array}{l}98 * * * \\
(41-302)\end{array}$ & $\begin{array}{l}103 * * * \\
(52-339)\end{array}$ & $\begin{array}{l}227 * * * \\
(80-483)\end{array}$ & $\begin{array}{l}158 * * * \\
(92-436)\end{array}$ \\
\hline $\begin{array}{l}\mathrm{PaCO}_{2} \\
(\mathrm{~mm} \mathrm{Hg})\end{array}$ & $\begin{array}{l}37 \\
(6-80)\end{array}$ & $\begin{array}{l}29 \\
(6-78)\end{array}$ & $\begin{array}{l}36 \\
(11-81)\end{array}$ & $\begin{array}{l}47 \\
(15-96)\end{array}$ & $\begin{array}{l}28^{*} \\
(19-69)\end{array}$ & $\begin{array}{l}33 * \\
(13-71)\end{array}$ & $\begin{array}{l}22 * \\
(7-57)\end{array}$ & $\begin{array}{l}21^{*} \\
(6-66)\end{array}$ \\
\hline $\begin{array}{l}\mathrm{V}_{\mathrm{T}} \\
(\mathrm{ml})\end{array}$ & $\begin{array}{l}96 \\
55-119)\end{array}$ & $\begin{array}{l}98 \\
(51-130)\end{array}$ & $\begin{array}{l}67 \\
(43-99)\end{array}$ & $\begin{array}{l}73 \\
(53-128)\end{array}$ & $\begin{array}{l}73 \\
(49-96)\end{array}$ & $\begin{array}{l}73 \\
(36-111)\end{array}$ & $\begin{array}{l}66 \\
(34-103)\end{array}$ & $\begin{array}{l}63 \\
(35-88)\end{array}$ \\
\hline $\mathrm{V}_{\mathrm{D}} / \mathrm{V}_{\mathrm{T}}$ & $\begin{array}{l}0.94 \\
(0.8-1.0)\end{array}$ & $\begin{array}{l}0.93 \\
(0.8-1.0)\end{array}$ & $\begin{array}{l}0.93 \\
(0.6-1.0)\end{array}$ & $\begin{array}{l}0.94 \\
(0.7-1.0)\end{array}$ & $\begin{array}{l}0.93 \\
0.8-1.0)\end{array}$ & $\begin{array}{l}0.93 \\
(0.7-1.0)\end{array}$ & $\begin{array}{l}0.85 \\
(0.4-0.9)\end{array}$ & $\begin{array}{l}0.86 \\
(0.6-0.96)\end{array}$ \\
\hline $\begin{array}{l}\mathrm{AaDO}_{2} \\
(\mathrm{~mm} \mathrm{Hg})\end{array}$ & $\begin{array}{l}550 \\
(298-576)\end{array}$ & $\begin{array}{l}540 \\
(301-577)\end{array}$ & $\begin{array}{l}559 \\
(248-576)\end{array}$ & $\begin{array}{l}558 \\
(434-572)\end{array}$ & $\begin{array}{l}527 * * * \\
(324-594)\end{array}$ & $\begin{array}{l}519 * * * \\
(304-594)\end{array}$ & $\begin{array}{l}413 * * * \\
(169-567)\end{array}$ & $\begin{array}{l}480 * * \\
(208-551)\end{array}$ \\
\hline $\mathrm{pH}$ & $\begin{array}{l}7.2 \\
(6.6-7.6)\end{array}$ & $\begin{array}{l}7.1 \\
(6.6-7.8)\end{array}$ & $\begin{array}{l}7.0 \\
(6.7-7.4)\end{array}$ & $\begin{array}{l}6.9 \\
(6.6-7.4)\end{array}$ & $\begin{array}{l}7.2 \\
(6.7-7.5)\end{array}$ & $\begin{array}{l}7.2 \\
(6.7-7.5)\end{array}$ & $\begin{array}{l}7.2 \\
(6.7-7.7)\end{array}$ & $\begin{array}{l}7.1 \\
(6.6-7.7)\end{array}$ \\
\hline $\begin{array}{l}\mathrm{BE} \\
(\mathrm{mmol} / \mathrm{l})\end{array}$ & $\begin{array}{l}-14.6 \\
(-0.7- \\
-29.3)\end{array}$ & $\begin{array}{l}-17 \\
(-6.5- \\
-29.3)\end{array}$ & $\begin{array}{l}-20.8 \\
(-8.2- \\
-28.3)\end{array}$ & $\begin{array}{l}-22.8 \\
(-12.4- \\
-29.3)\end{array}$ & $\begin{array}{l}-15.0 \\
(-1.9- \\
-26.9)\end{array}$ & $\begin{array}{l}-16.9 \\
(-5.4- \\
-27.6)\end{array}$ & $\begin{array}{l}-18.5 \\
\left(\begin{array}{c}-4.3- \\
-28.9\end{array}\right)\end{array}$ & $\begin{array}{c}-22.2 \\
(-6.8- \\
-29.9)\end{array}$ \\
\hline $\begin{array}{l}\text { Lactate } \\
(\mathrm{mmol} / \mathrm{l})\end{array}$ & & $\begin{array}{l}9.4 \\
(4.6-17)\end{array}$ & & $\begin{array}{l}12.7 \\
(8.7-16.3)\end{array}$ & & $\begin{array}{l}12.4 \\
(5.4-17)\end{array}$ & & $\begin{array}{l}12.9 \\
(7.4-17)\end{array}$ \\
\hline $\begin{array}{l}\mathrm{VCO}_{2} \\
(\mathrm{ml} / \mathrm{min})\end{array}$ & $\begin{array}{l}7.6 \\
(1.4-2.5)\end{array}$ & $\begin{array}{l}6.7 \\
(0-22.7)\end{array}$ & $\begin{array}{l}6.5 \\
(2.9-15.3)\end{array}$ & $\begin{array}{l}5.3 \\
(1.5-13.5)\end{array}$ & $\begin{array}{l}10.4 \\
(4.2-17.2)\end{array}$ & $\begin{array}{l}10.5 \\
(4.0-26.9)\end{array}$ & $\begin{array}{l}8.8 \\
(3.3-26.3)\end{array}$ & $\begin{array}{l}8.7 \\
(1.7-15.2)\end{array}$ \\
\hline
\end{tabular}

${ }^{* * *} \mathrm{p}<0.001,{ }^{* *} \mathrm{p}<0.01,{ }^{*} \mathrm{p}<0.05$ 


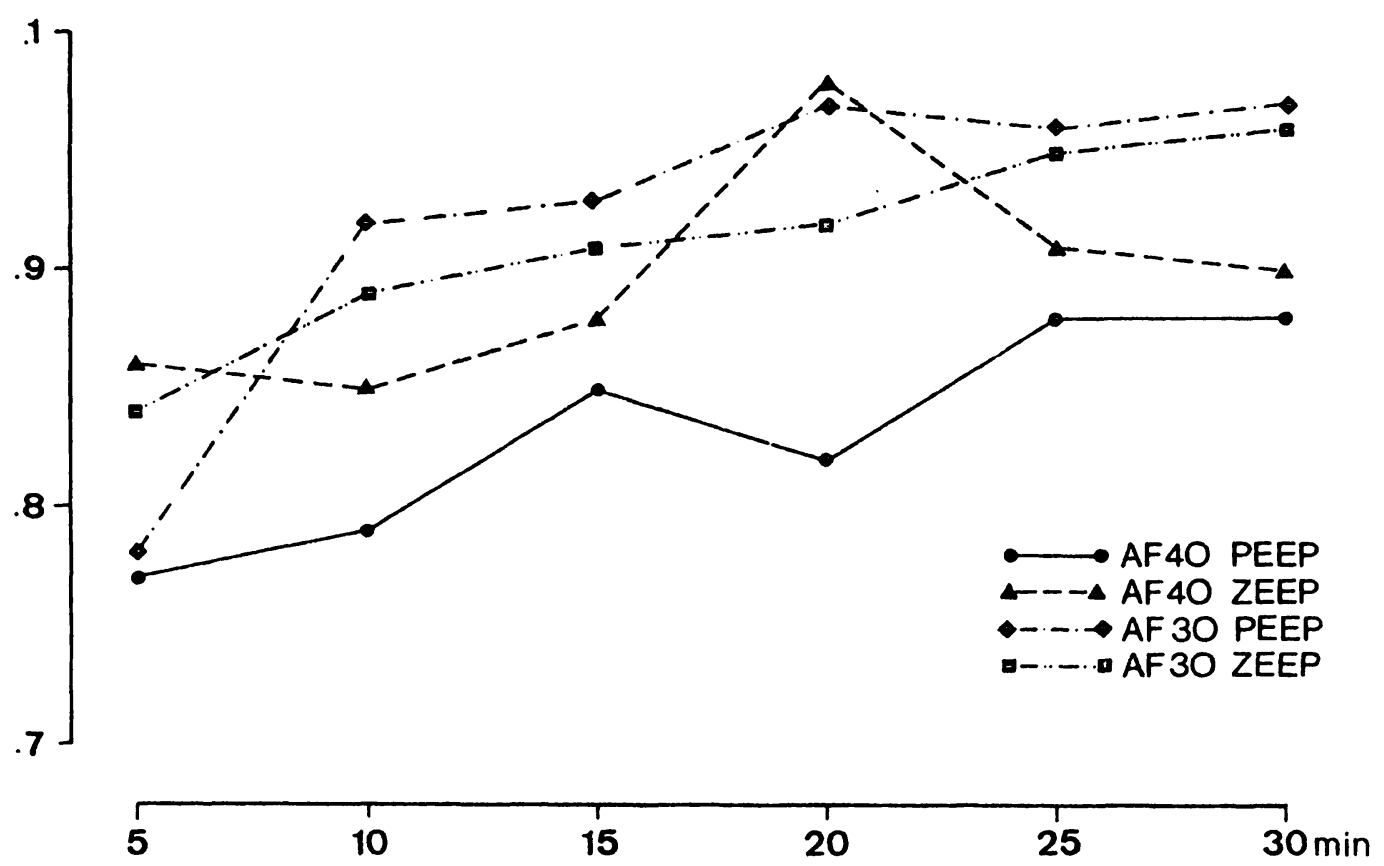

Fig. 7. $V_{D} / V_{T}$ during the course of cardiopulmonary reanimation using a respiratory rate of either 30 or $40 / \mathrm{min}$ and either ZEEP or PEEP. (Median values).

values, in part very marked, during the cause of the thirty minute period of reanimation. The metabolic changes were the most markedly different from the norm while respiratory and circulatory parameters showed less marked alteration.

The fact that similarly high lactate levels were found in all groups, indicates that reanimation technique remained unchanged during the investigation.

Mean systolic pressures between 75 and $80 \mathrm{~mm} \mathrm{Hg}$ were registered during cardiac compression. In between compressions a pressure of approximately $5 \mathrm{~mm} \mathrm{Hg}$ was measured in the arterial system, a value which corresponds to the hydrostatic pres-
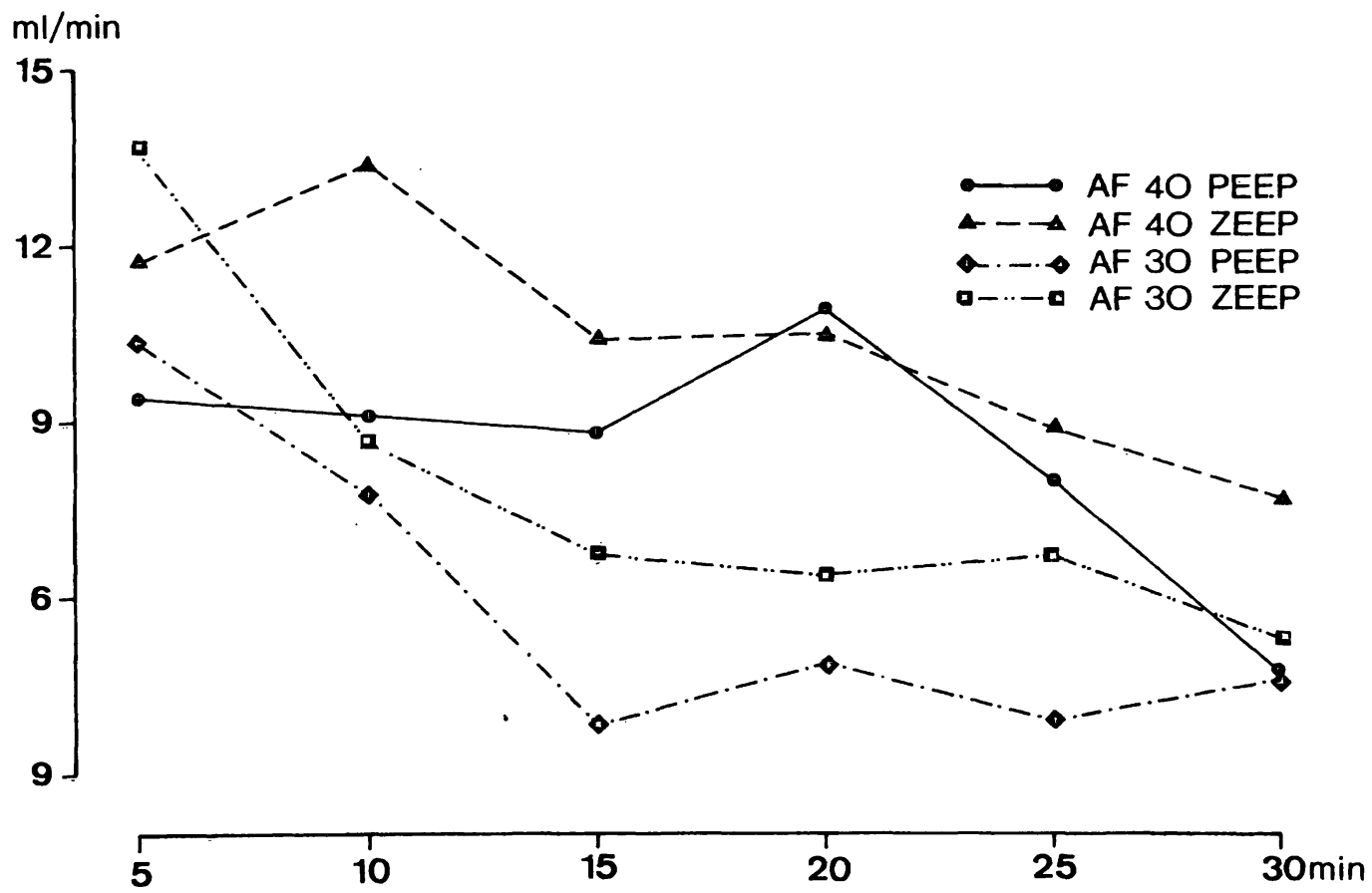

Fig. 8. $\mathrm{CO}_{2}$-production during the course of cardiopulmonary reanimation using respiratory rates of either 30 or $40 / \mathrm{min}$ and either ZEEP or PEEP. (Median values). 
sure of stationary blood [8]. The measured mean values of approximately $25 \mathrm{~mm} \mathrm{Hg}$ were hence very low. Failures in measurement were excluded by taking separate recordings from both the abdominal aorta and the femoral artery. The slightly lower pressure values at $10 \mathrm{~min}$. can probably be explained by the reanimator becoming somewhat tired.

Ventilation with $100 \%$ oxygen resulted in an adequate arterial oxygenation in all groups. This, despite the fact that alveolar ventilation was only between 10 and $15 \%$ of the respiratory minute volume. The high dead space ratio and alveolararterial difference in partial pressure of oxygen indicate that a marked disturbance of pulmonary blood distribution, ventilation and perfusion is occurring under these conditions. Comparison of the various ventilation: compression ratios used showed no significant differences in respiratory or hemodynamic parameters. If the $\mathrm{CO}_{2}$-production is regarded as a measurement of aerobic metabolism and hence as an indirect measure of the efficacy of reanimation, then our results indicate that the use of a ventilation: compression ratio $1: 3$ as compared to $1: 2,1: 4,1: 5$, is that which should be used. The fact that this ratio is in accordance with the physiological, respiratory and circulatory parameters of the neonate (respiratory rate of approximately $40 / \mathrm{min}$, heart rate of approximately $120 / \mathrm{min}$ ) supports these results.

The effect on arterial oxygenation also indicates that the respiratory rate of $40 / \mathrm{min}$ should be used. The markedly improved $\mathrm{CO}_{2}$-output when this frequency is used is a further indication in this direction. It seems possible that on using this higher respiratory rate cardiac compression and ventilation are more often concomitant, and, as in the technique of "new cardio - pulmonary resuscitation" a more marked increase in intrathoraxic pressure and blood flow is so achieved [11].

Comparison of the use of a respiratory rate of $40 / \mathrm{min}$ without the use of the positive endexspiratory pressure of $5 \mathrm{~cm}$ of water with use of a respiratory rate of $30 / \mathrm{min}$ and either ZEEP or PEEP shows an improvement in arterial partial pressure of oxygen of only 100 from otherwise $70 \mathrm{~mm} \mathrm{Hg}$. When a respiratory rate of $40 / \mathrm{min}$ is combined with the use of PEEP however a highly significant increase in $\mathrm{PaO}_{2}$, an improvement in $\mathrm{AaDO}_{2}$ and a decrease in dead space volume is found.

Both PEEP-groups had higher base excess and lower $\mathrm{CO}_{2}$-production values than those animals ventilated with $Z E E P$, a significant difference could not be calculated however.

The animals which were ventilated with a respiratory rate of 40 and PEEP had better values prior to cardiac arrest than the animals ventilated at $40 /$ min with ZEEP, it is therefore difficult to say whether the more physiological parameters found in the former group are a result of the PEEPventilation used, or are only a reflection of the better initial values of these animals. Animal experiments carried out by HODGKIN et al. [9] on pigs of body weight between 14 and $26 \mathrm{~kg}$ also showed a markedly better degree of oxygenation under the combined use of a respiratory rate of 40/min and PEEP, so that this technique is indeed probably the best.

\section{Conclusions}

Basing reanimation technique on the known physiological data of the neonate (respiratory rate of about $40 / \mathrm{min}$ and heart rate of approximately $120 / \mathrm{min}$ ) results in a ventilation: compression ratio of $1: 3$, or multiples thereof. No marked disadvantages of ventilation: compression ratios higher or lower than $1: 3$ could be shown in this study, on the other hand, no advantages of the various other ratios could be found either.

For these reasons we are of the opinion that neonatal cardiopulmonary reanimation should be carried out at a respiratory rate of 40 and cardiac compression rate of $120 / \mathrm{min}$, from which follows that a ratio of $1: 3$, or multiples thereof, should be used, rather than the previously recommended ratio of $1: 5$, which has neither physiological nor experimental foundation.

Furthermore, because better oxygenation can so be achieved, and because the majority of low APGAR neonates have a high pulmonary restriction, positive end expiratory pressure ventilation using approximately $5.0 \mathrm{~cm}$ of water should be applied as soon as possible. 


\section{Summary}

Study of the literature on the cardiopulmonary reanimation of low APGAR neonates reveals wide descrepancies in the recommendations given respect to ventilation and cardiac compression rates, and the ratio of these two factors to each other. While most authors agree in suggesting a ventilation rate of between 30 and 40 per minute, the recommended rate of cardiac compression varies widely from 60 , up to 140 per minute.

Based on the experience gained with adult reanimation procedures, most sources, including the AMERICAN HEART ASSOCIATION [1], recommend a ventilation: compression ratio of $1: 5$. The above mentioned rates make this untenable however.

In order to determine which ventilation: compression ratio is most suitable, studies were carried out on 24 piglets of body weight between 4 and $5 \mathrm{~kg}$ which were first anaesthetized, given muscle relaxants and intubated. Following chemically induced cardiac arrest, the animals were then reanimated using respiratory rates between 30 and 40 per minute and cardiac compression rates between 60 and 160 per minute at ventilation: compression ratios of $1: 2,1: 3$ and $1: 4$. The addition, the effect of applying a PEEP of $5 \mathrm{~cm}$ of water was evaluated.

Measurement of arterial blood gases and acid-base status, arterial blood pressure, serum lactate concentration, expiratory $\mathrm{CO}_{2}$ levels, dead space volume, and the alveoloarterial difference in partial pressure of oxygen revealed that respiratory parameters were best improved when a respiratory rate of 40 per minute and a PEEP of $5 \mathrm{~cm}$ of water was applied, and that none of the ventilation: compression ratios used brought about a marked change in respiratory or haemodynamic parameters. In so far as $\mathrm{CO}_{2}$-production can be regarded as an indicator of the degree of aerobic metabolish occurring, and hence as an indirect measure of the efficacy of the reanimation procedure applied, our results indicate that the use of a $1: 3$ ratio is more effective than ratios of $1: 2,1: 4$ or even $1: 5$.

Basing reanimation technique on the known physiological data of the neonate (respiratory rate of about 40 per minute and heart rate of approximately 120 per minute) results in a ventilation: compression ratio of $1: 3$, or multiples thereof. No marked disadvantages of ventilation: compression ratios higher or lower than $1: 3$ could be shown in this study, on the other hand, no advantages of the various other ratios could be found either.

For these reasons we are of the opinion that neonatal cardiopulmonary reanimation should be carried out at a respiratory rate of 40 and cardiac compression rate of 120 per minute, from which follows that a ratio of $1: 3$, or multiples thereof, should be used, rather than the previously recommended ratio of $1: 5$, which has neither physiological nor experimental foundation.

Furthermore, because better oxygenation can so be achieved, and because the majority of low APGAR neonates have a high pulmonary restriction, positive end expiratory pressure ventilation using approximately $5.0 \mathrm{~cm}$ of water should be applied as soon as possible.

Keywords: Cardiac compression massage, newborn, PEEP, reanimation, ventilation compression ratio.

\section{Zusammenfassung}

Tierexperimentelle Untersuchungen zur kardiopulmonalen Reanimation Neugeborener

Die Empfehlungen zur Durchführung der kardiopulmonalen Reanimation schwer deprimierter Neugeborener in der Literatur enthalten bezüglich der Frequenz von Beatmung und Herzdruckmassage sowie deren Relation zueinander sehr unterschiedliche Angaben. Während die Beatmungsfrequenz mit $30-40 / \mathrm{min}$ relativ einheitlich angegeben wird, umfassen die empfohlenen Thoraxkompressionen einen Frequenz bereich zwischen 60 und 140/min.

Ausgehend von der bei Erwachsenen geübten Reanimationspraxis empfiehlt die Mehrzahl der Autoren - so auch die AMERICAN HEART ASSOCIATION [1] - ein Beatmungs-Kompressions-Verhältnis von $1: 5$. Dieses Vorgehen erscheint nicht sinnvoll, legt man die oben angeführten Daten zugrunde.

Mit dem Ziel optimale Ventilations-Kompressions-Raten zu ermitteln, wurden bei 24 narkotisierten, endotracheal intubierten und relaxierten Jungschweinen mit einem Körpergewicht von 4-5 kg nach Erzeugen eines Herzstillstandes die Reanimationsmaßnahmen durch Beatmungsfrequenzen zwischen 30 und 40 und Kompressionsfrequenzen zwischen 60 und $160 / \mathrm{min}$ variiert und jeweils ein Ventilations-Kompressions-Verhältnis von $1: 2,1: 3$ und 1:4 zur Anwendung gebracht. Zusätzlich wurde der
Einfluß eines positiv endexspiratorischen Druckes von $5 \mathrm{~cm} \mathrm{H}_{2} \mathrm{O}$ geprüft.

Aus den arteriellen Blutgasen, dem Säuren-Basen-Status, dem arteriellen Druck, den Laktatkonzentrationen und der $\mathrm{CO}_{2}$-Messung in der Exspirationsluft sowie der Totraumventilation und der alveolo-arteriellen Partialdruckdifferenz kamen wir zu folgendem Ergebnis:

Die Parameter des Gasaustausches zeigten unter der höheren Atemfrequenz von $40 / \mathrm{min}$ bei gleichzeitiger Anwendung eines positiv endexspiratorischen Druckes von $5 \mathrm{~cm} \mathrm{H}_{2} \mathrm{O}$ eine deutliche Verbesserung.

Legt man die physiologischen, respiratorischen und zirkulatorischen Größen des Neugeborenen (Atemfrequenz ca. 40/min, Herzfrequenz ca. $120 / \mathrm{min}$ ) zugrunde, ergibt sich daraus ein Ventilations-Kompressions-Verhältnis von 1:3 oder einem Vielfachen davon. Unsere Untersuchungen ließen zwar keine gravierenden Differenzen zwischen den verschiedenen Beatmungs-KompressionsVerhältnissen erkennen, höhere oder niedrigere Relationen als 1: 3 waren jedoch umgekehrt ebenfalls nicht von Vorteil. Aus diesen beiden Gründen sollte unseres Erachtens für die kardiopulmonale Reanimation des Neugeborenen eine Beatmungsfrequenz von ca. $40 / \mathrm{min}$ und eine Kompressionsfrequenz von ca. $120 / \mathrm{min}$ und damit eine Beatmungs-Kompressions-Relation von $1: 3$ oder einem 
Vielfachen davon anstelle der bisher empfohlenen und durch nichts begründbaren Relation von 1:5 angewendet werden.

Die besseren Oxygenierungsbedingungen und die Tatsache, daß die Mehrzahl schwer depremierter Neugebore- ner erhebliche restriktive Lungenveränderungen aufweist, legt darüber hinaus - wie diese und frühere Untersuchungen belegen - die primäre' Anwendung eines positiv endexspiratorischen Drucks in der Größenordnung um $5 \mathrm{~cm}$ $\mathrm{H}_{2} \mathrm{O}$ nahe.

Schlüsselwörter: Herzdruckmassage, Neugeborenes, PEEP, Reanimation, Ventilations-Kompressions-Verhältnis.

\section{Résumé}

Etude experimentale sur l'animal de la réanimation cardio-pulmonaire des nouveaux-nés

L'étude de la littérature sur la réanimation cardio-pulmonaire de nouveaux-nés d'APGAR bas révèle le grosses différences sur les recommandations données concernant le respect des fréquences de ventilation et de massage cardiaque et la fréquence de ces 2 facteurs l'un par rapport à l'autre.

Alors que la plupart des auteurs s'accordent pour suggérer une fréquence de ventilation entre 30 et 40 par minute, la fréquence recommandée du massage cardiaque varie largement de 60 à 140 par minute.

De nombreuses sources, comprenant les conclusions de l'AMERICAN HEART ASSOCIATION de 1980 [1], fondées sur les techniques de réanimation chez l'adulte, recommandent un rapport ventilation/massage de $1 / 5$. Toutefois les fréquences mentionnées ci-dessus rendent cela irréalisable.

Dans le but de déterminer quel rapport ventilation/ massage est le plus approprié, une étude a été entreprise sur 24 cochons de lait de poids corporel compris entre 4 et $5 \mathrm{~kg}$ primitivement anesthésiés, sous myorelaxants et intubés. A la suite d'un arrêt cardiaque d'induction chimique, les animaux sont ensuite réanimés en utilisant une fréquence respiratoire entre 30 et 40 par minute et une fréquence de massage cardiaque entre 60 et 160 par minute, avec des rapports ventilation/massage de $1 / 2,1 / 3$ et $1 / 4$. En outre, l'effet de l'application d'une PEEP de $5 \mathrm{cms}$ d'eau a été estimé.

La mesure des gaz sanguins artériels et de l'équilibre acidobasique, pression sanguine artérielle, lactates sériques, niveaux de $\mathrm{CO}_{2}$ expiratoire, volume de l'espace mort et la différence alveolo-artérielle de la pression partielle en oxygène, a mis en évidence que les paramètres respiratoires sont les meilleurs avec une fréquence respiratoire de 40 par minute et une PEEP de $5 \mathrm{cms}$ d'eau utilisée, et que aucun des rapports ventilation/massage utilisés n'a entraîné de modification importante au niveau des paramètres respiratoires ou hémodynamiques. Pour autant que la production de $\mathrm{CO}_{2}$ puisse être considérée comme une mesure indirecte de l'efficacité des techniques de réanimation, nos résultats indiquent que l'utilisation d'un rapport $1: 3$ est plus efficace que les rapports $1: 2$, $1: 4$ et même que $1: 5$.

En fondant les techniques de réanimation sur les données physiologiques connues concernant le nouveau-né (fréquence respiratoire d'environ 40 par minute et fréquence cardiaque d'approximativement 120 par minute), on aboutit à un rapport ventilation/massage de $1 / 3$, ou multiple de celui-ci. Dans cette étude, il n'a pu être mis en évidence de désavantage notable avec des rapports ventilation/massage plus élevés ou plus bas que $1 / 3$, d'un autre côté aucun avantage n'a pu être trouvé avec divers autres rapports.

Pour ces raisons, nous estimons que la réanimation cardiopulmonaire néonatale devrait être conduite avec une fréquence respiratoire de 40 et une fréquence de massage cardiaque de 120 par minute, d'où il découle qu'un rapport de $1 / 3$, ou multiple de celui-ci, devrait être préféré, plutôt qu'un rapport de $1 / 5$ auparavant préconisé, rapport qui ne repose sur aucun support physiologique ou expérimental.

Par ailleurs, parce qu'une meilleure oxygénation peut aussi être assurée et parce que la majorité des nouveauxnés avec un APGAR bas ont des résistances pulmonaires élevées, on devrait utiliser dès que possible une pression ventilatoire positive de fin d'experation d'environ $5 \mathrm{~cm}$ d'eau.

Mots-clés: Massage cardiaque, nouveaux-nés, PEEP, réanimation, pression ventilatoire (fréquences du massage, de la ventilation).

\section{Bibliography}

[1] AMERICAN HEART ASSOCIATION: Standards and guidelines for cardiopulmonary resucitation (CPR) and emergency cardiac care (ECC). Jama 244 (1980) 453

[2] BAUER, R. O.: Obstetrical analgesia and anesthesia and resuscitation of neonates. Int. Anaesthesiol. Clin. 9 (1971) 63

[3] BEUTNAGEL, H., K. H. WULF: Reanimation des Neugeborenen. Med. Klin. 68 (1973) 1
[4] DICK, W., F. W. AHNEFELD: Primäre Neugeborenen-Reanimation. Springer-Verlag, Berlin - Heidelberg - New York 1975

[5] DORAND, R. D.: Neonatal asphyxia. An approach to physiology and management. Pediatric Clinics of North America 24 (1977) 455

[6] Finster, M.: Resuscitation of the newborn. Acta anaesth. Scand. Suppl. 37 (1970) 86

[7] GREGORY, G. A.: Resucitation of the newborn. Anesthesiology 43 (1975) 225 
[8] HÄRICH, B. K. S., M. PROBST, F. W. AHNEFELD: Ein Beitrag zur Verbesserung der extrathorakalen Herzdruckmassage (HDM) nach hämodynamischen Kriterien am Menschen. Intensivmed. 16 (1979) 249

[9] HODGKIN, B. C., C. T. LAMBREW, F. H. LAWRENCE, E. T. ANGELAKOS: Effects of PEEP and of increased frequency of ventilation during CPR. Critical Care Medicine 8 (1980) 123

[10] LAZZARA, A.: Resuscitation of the newborn. Postgrad. Med. 61 (1977) 203

[11] LUCE, J. M., J. M. CARY, B. K. ROSS, B. H. CULVER, J. BUTLER: New developments in cardiopulmonary resuscitation. Jama 244 (1980) 1366

[12] RIEGEL, K., H. WELSCH: Akutversorgung des Risikoneugeborenen. Z. Geburtsh. u. Perinat. 117 (1973) 1

[13] SEIDAT, K. H.: Zur Reanimation beim Kind. Z. Kinderchir. Suppl. 11 (1972) 201
[14] STOLL, W.: Die primäre Reanimation des Neugeborenen. Enke, Stuttgart 1975

[15] THALER, M. M., G.H. C. STOBIE: An improved technic of external cardiac compression in infants and young children. New. Eng. J. Med. 269 (1963) 606

Received August 16, 1982. Accepted November 19, 1982.

Dr.med. Edeltrude Traub Zentrum für Anästhesiologie der Universität Ulm Prittwitzstraße 43 D-7900 Ulm/Donau FRG 